\title{
Hydrogeophysical characterization of aquifers in Upper Denkyira East and West Districts, Ghana
}

\author{
Victor Ofori Agyemang ${ }^{1}$
}

Received: 7 June 2020 / Accepted: 20 June 2021 / Published online: 3 July 2021

(c) The Author(s) 2021

\begin{abstract}
Hydrogeophysical assessment of aquifers in the Upper Denkyira East and West Districts of Ghana has been carried out for groundwater potential and protective capacity of the overburden rocks determination. The data for the study were obtained from the Regional office of Community Water and Sanitation Agency (CWSA), Cape Coast. A total of thirty-seven VES probed using a Schlumberger array with maximum current electrode spacing $(\mathrm{AB} / 2)$ of $100 \mathrm{~m}$ at each point using the Abeam Terameter was used. The data were interpreted using the partial curve matching and WINRESIST computer iteration program techniques. The thickness and resistivities of the various overburden layers, basement resistivity, reflection coefficient and longitudinal conductance were used for the assessment of the groundwater potential and the protective capability of the overburden layers. The study revealed three-to-six layers with an average of four (4) layers including laterite (0.34-3.57 m); clay $(0.64-8.84 \mathrm{~m})$; sandy-clay $(0.67-27.09 \mathrm{~m})$ and slightly-to-highly weathered bedrock which includes phyllites and granite $(3.09-86.89 \mathrm{~m})$ that show high level of heterogeneity of electrical resistivity of the geologic materials within the study area. The weathered layers serve as the aquiferous zones. About $21.6 \%, 62.2 \%, 2.7 \%$ and $13.5 \%$ showed high, medium, low and very low potential for groundwater, respectively, with higher groundwater potentials at the western and south-eastern corner of the study area underlain by the Birimian and Tarkwaian formations, respectively, indicating that the two formations have similar groundwater potentials in the study area. The lowest groundwater potential was observed at the point underlain by the granitic intrusion. The assessment of the protective capacity of the aquifer showed very good (5\%), good (27\%), moderate (19\%), weak (22\%) and poor (27\%) indicating that the study area is overlain mostly by materials of different protective capacities. This study presents information on the aquifer protective capacity evaluation by using geophysical technique and it has revealed that the Birimian formation has a good aquifer protective capacity than the Tarkwaian formation and has also confirmed the effectiveness of using geophysical techniques in ground investigation.
\end{abstract}

Keywords Groundwater potential · Aquifer protective capacity · Vertical electrical sounding · Birimian supergroup · Upper Denkyira East and West Districts

\section{Introduction}

Over the years, there have been challenges in meeting the water demand in all parts of the world. The continuous increase in the uncertainty of water availability due to the impacts of factors such as high population growth rate, climate change and improved technology that demands water resources. Effective water resource management is the key to ensure the sustainability of natural resources. This

Victor Ofori Agyemang

oforiagyemangvictor@yahoo.com

1 Community Water and Sanitation Agency, Hydrogeological Unit, P. O. Box 128, Damongo, Ghana management is dependent on the available data for making informed decisions on the water resources. Some researchers have characterized aquifers in different parts of the world using evidence from hydrogeological data acquired using VES which were interpreted to reveal the characteristics of the aquifer as well as the subsurface lithological succession (Clark 1985; Jones 1985; Olayinka 1996; Oladapo and Akintorinwa 2007; Golam 2014; Ogunrayi et al. 2016). Different geoelectric layers and curve types may be obtained across a study area. Layer resistivities and thicknesses can be used to deduce parameters such as transverse resistance $(T)$, longitudinal conductance $(S)$, coefficient of anisotropy $(l)$, and reflection coefficient $(r)$ (Bhattacharya and Patra 1968; Henriet 1976; Loke 1999). The existence of human 
being depends on the availability of safe water, and the total dependence on water for life calls for a continuous supply of potable water. There is a need to improve the techniques in the groundwater search due to the continuous loss of surface water to contamination and/or climate change. The high cost of treating highly polluted surface water makes the groundwater an ideal source for domestic, industrial and other water needs; hence, the exploration of groundwater is very essential.

Besides the use of groundwater for drinking and domestic purposes, it is also used for irrigation and other agricultural purposes in all parts of the world due to irregular natural rainfall pattern (Margat and Gun 2013). The global demand for groundwater for water needs is reaching an alarming rate and gives a bad signal for the future danger which may be worsened by climate change and increased population size (EEA 1999; UNECE 1999). For effective water resource management, there is a need for the availability of information on water quality and quantity and their change with time and space. Natural pores and fractured zones within rocks serve as the channel for the flow of groundwater below the surface of the earth (Golam 2014). In a typical basement environment, the flow of the groundwater occurs within the weathered, fractured faulted zones. However, the flow occurs through porous and permeable layers of the saturated zone in sedimentary rocks.

Over the years, the application of geophysical methods in groundwater exploration has gain popularity, and there has been great advancement in data acquisition, processing and interpretation. Several geophysical methods are used in different areas and for different purposes. The vertical electrical-sounding geophysical technique is one of the techniques that is widely used in groundwater exploration globally due to its efficiency. It is one of the oldest geophysical techniques used in the studying of the earth and is still being used. Schlumberger and Wenner started using the method in 1912 and the method has gone through advancement in instrumentation, data acquisition, processing and interpretation. According to Pous et al. (1996) in the early years, the major research focus on VES was to minimize the effects of surface inhomogeneities and two-dimensional bodies. A lot of experimentation took place until the problem was solved by the recent advent of the resistivity imaging technique. Abbas et al. (2004) applied geoelectric sounding taking account of near-surface inhomogeneities in the semi-arid and arid area characterized by a sequence of sedimentary rocks formed over a long geologic period with an unconformity that separates it from the underlying igneous and metamorphic rocks in Egypt. The alluvium fan of Wadi Watir is of quaternary age, and it is the major water-bearing formation and groundwater that occur in different types of lithological compositions under unconfined and confined conditions. Abbas et al. (2004) attempted the use of one-dimensional VES in cases where neither two-dimensional nor three-dimensional survey equipment was not available nor this has improved the one-dimensional survey technique by better estimation of geoelectrical parameters known as the Dar Zarrouk parameters. They also provided a method of studying the geologic conditions of the study area by the use of a two-dimensional representation of the number of the VES that have the same range of resistivity values at discrete half current electrode distance $(\mathrm{AB} / 2)$ and the plot revealed the dominant curve type for the area which indicated is interpreted the presence of continuous geologic structures. They calculated Dar Zarrouk parameters calculated for the aquifer to examine its quality where the values of transverse resistance greater than $9000 \Omega-\mathrm{m}^{2}$ were considered to indicate saltwater and this approach help them to successfully identify areas of preferable groundwater exploration and drilling. Application of VES in groundwater exploration occurs all over the world over the years (Henriet 1976; Clark 1985; Ogunrayi et al. 2016). The application of the VES technique using the Schlumberger array method was carried out at 16 VES points to determined resistivities and thicknesses of the subsurface layers and their hydrogeological properties. This study aimed at evaluating the groundwater potential of the area, establishing the aquifer protective capacity of the overlying formations, especially its isolation from contamination, and recommending suitable points for borehole drilling. The application of VES in groundwater studies is well documented in the literature (Keller and Frischknecht 1966; Keller 1967; Henriet 1976; Koefoed 1979; Kosinski and Kelly 1981).

In Ghana, groundwater is mainly used for the domestic purposes since there is no supply of treated water in villages and small towns, and most of the surface water bodies are contaminated. The major source of water in the Upper Denkyira East and West Districts is the groundwater. However, the district is also rich in gold mineralization which has attracted both large scales, small scale and illegal mining activities. These activities together with other anthropogenic activities such as agriculture in the district present major challenges in the groundwater management. The increasing demand for groundwater in the district calls for means to guarantee effective management of the groundwater resources and to ensure that the groundwater supplied for use by the public meets the drinking, domestic and irrigation water quality standards. It is, therefore, necessary to assess the groundwater resources potential and the protective potential of the overburden layers that protect the aquifer from being contaminated by fluids from the surface. However, there is limited information on the local aquifers' groundwater potentials and their protective capacities. Therefore, this study seeks to characterize the aquifers in the study area to assess their groundwater potentials and their protective capacities. Locally, the occurrence of groundwater in the study area is controlled by the underlying Birimian 
meta-sediments and the Tarkwaian formation which hydraulic properties dependent on the secondary permeability created by fractures, quartz stringers, veins and shear zones that improve groundwater flow and storage. With the dependence on the secondary hydraulic properties coupled with the heterogeneity of the aquifer, groundwater flow within the aquifers occurs mainly in the fractures and other discontinuities rather than as interstitial flow. The overlying shallower weathered bedrock profiles tend to form a confining unit to this aquifer, and the shallow quaternary sediments associated with drainage lines, if saturated, would be too thin to form useful aquifers but may form perched aquifers that support remnant vegetation. At least on a large scale, the groundwater flow would be heterogeneous and fracture-flow dominated and may also be compartmentalized into separate strip aquifers across the site (CAGL 2010). Coffey (2007) conducted terrain analysis of the regional topography and concluded that the groundwater in the study area flows toward the Offin River. However, the analysis of static water level of twenty-five inclined exploration holes drilled by Sun Gold Limited showed that the groundwater flow is radial within the study area (CAGL 2010). According to Jay Minerals Services Limited (1993), the estimated aquifer recharge of the area is $3-5 \%$ of the total annual rainfall. However, CAGL (2010) reported an estimated recharge of $15 \%$ of the total precipitation which varies locally and regionally from 1 to $20 \%$. Examination of drilled logs of exploration holes depth of aquiferous zone to range between 6 and $92 \mathrm{~m}$ with a mean of $22.4 \mathrm{~m}$ revealing the presence of both shallow and deep-seated aquifers in the study area (CAGL 2010). Hydrogeological studies of the weathered rock in the existing pits in the study area indicated rock mass permeability in the order of $0.1-0.01 \mathrm{~m} /$ day where higher values were associated with the structural features within the pits which indicate that the rock mass permeability as a whole is probably as low as $0.001 \mathrm{~m} /$ day (CAGL 2010). In November 2006, a site audit by a team from the European Union identified elevated levels of arsenic in seepage from sections of the heap leach pads and recommended that although elevated arsenic concentrations are not widespread, the situation warrants further observation and possible mitigation measures in the study area (CAGL 2010). This study aims to understand the groundwater potentials of the aquifers of the study area and the natural capabilities of the overburden rocks to prevent contaminant fluids from polluting the groundwater from the surface.

\section{Study area}

The study area is under a forest-dissected plateau, rises to about $250 \mathrm{~m}$ above sea level and generally has undulating relief with pockets of steep-sided hills that alternate with flat-bottomed valleys. The district is drained by the River Dia, River Offin and several streams such as the Subin Ninta,
Afiefi and Subin which are tributaries of the two rivers. The districts fall within the semi-equatorial zone with mean annual temperatures $30^{\circ} \mathrm{C}$ and $26^{\circ} \mathrm{C}$ on the hottest and the coolest months, respectively. It has two rainfall regimes with total annual mean rainfall ranging between 1200 and $2000 \mathrm{~mm}$ which spans from May to June, and from September to October, respectively, while the dry season occurs from November to February. The area is favorable for cocoa production; hence, the district is one of the leading producers in the region. The area is endowed with Gold and other natural mineral resources, and this has attracted more than ten mining companies that are currently operating in the districts. Also, many small-scale mining companies operate in the districts.

The study area is underlain by the Middle Precambrian hydrogeological unit which is extensively dominated by Birimian and Tarkwaian formations aligned in the northeastern and south-western directions (Fig. 1). Both Birimian and Tarkwaian formations consist of phyllite in relative abundance but they differ in age. The Birimian rocks are made up of metamorphosed volcanic and sedimentary rocks. They have been folded, metamorphosed under the greenschist-facies condition and invaded by granitoids during the Eburnean (Junner 1935; Leube et al. 1990). Abouchami et al. (1990) suggest that the rocks were deposited on deformed and metamorphosed basement rocks of not more than $50 \mathrm{Ma}$ old. The Birimian supergroup is made up of two major lithostratigraphic units, namely Birimian Sedimentary Basin and Birimian Volcanic Belts (Kesse 1985). The rocks of the Birimian formation are folded, foliated and these together with the faults, folds, foliations and joints of the formation enhance the permeability for groundwater, storage and transmission in the rocks (Junner 1935). The contact zone between the Birimian rocks and the granitoids is highly sheared; showing formed foliations oriented $\mathrm{N}-\mathrm{S}$. Also, aligned parallel to the plane of shearing is quartz and pegmatite veins. The rocks of the Birimian Sedimentary Basin are represented by a great thickness of isoclinally folded, steeply dipping, alternating phyllites, schistose greywackes, sheared conglomerates, slates and argillaceous beds with some tuffaceous schist and lava. As a result of the extensive shearing, schists dominate at the contact between the Birimian Sedimentary Basin rocks and granitic intrusives. The rocks are of politic origin, having been mud and silts with beds of coarser sediments (Kesse 1985). The Dixcove granite (G2) is a complex rock that intrudes into the Birimian metavolcanic and hence is volcanic belts granitoid. These rocks consist of soda-rich hornblende, biotite granite or granodiorites which grade into quartz diorite and hornblende diorite and are commonly tonalitic in composition. The rocks found in the study area include greywackes, phyllites, slates, schists, tuffs, conglomerate, mudstone, siltstones, granite and sandstones. Therefore, some common

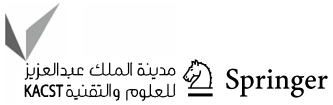




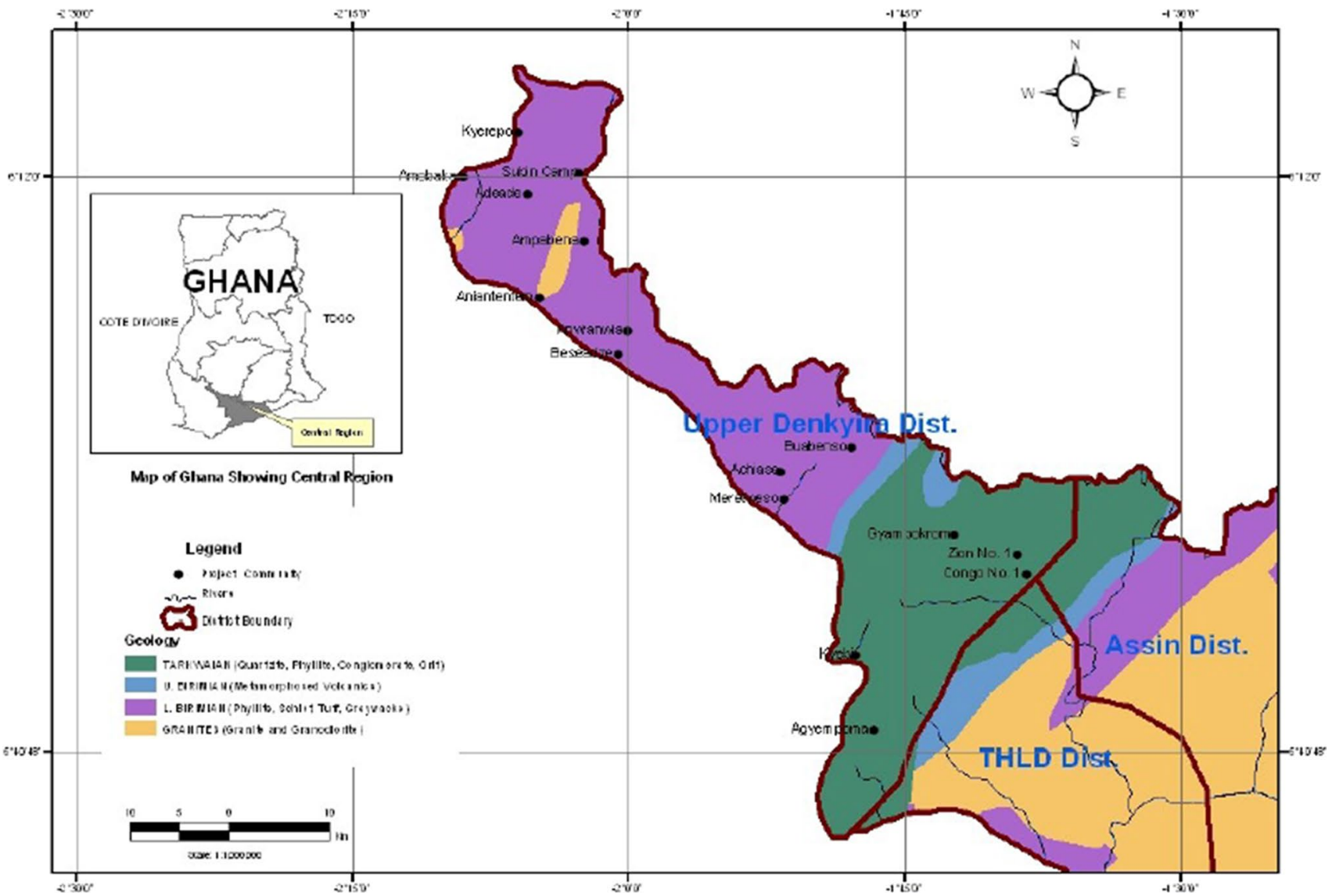

Fig. 1 Geological map of the study area (Okrah et al. 2012)

minerals in the area include orthoclase, plagioclase, quartz, biotite, muscovite, amphibole, hornblende, calcite, silica and chlorite. Anornu et al. (2009b, a) observed that there were poor relations between borehole yield and depths in the Birimian rocks. They concluded that the transmissivity of the boreholes varies between 0.12 and $125 \mathrm{~m}^{2} /$ day from pumping test data. According to the Ghana Geological Survey Department (GSD 2009), whereas the synvolcanic intrusive rocks were formed within the Birimian supergroup period (2195-2135 Ma), the undifferentiated intrusive granitoids were formed in the Eburnean Plutonic Suite period (2120-2115 Ma) as a result of partial melting of slightly older Birimian sediments during the Eburnean tectonothermal event. The synvolcanic granitoids yield a significant amount of groundwater than the undifferentiated intrusive granitoids, which is because the former has well-developed and connected fractures than the latter (Kesse 1985).

The Tarkwaian Group is made of a variety of sandstones, conglomerates and argillites, and its occurrences have been found on the eastern margin of the Sefwi Belt, in the KibiWinneba belt and the northern Nangodi Belt beside the study area (Griffis et al. 2002). The Tarkwaian is subdivided into four major units, which are, from the base to the top: the Kawere Group; the Banket Series; the Tarkwa Phyllite; and the Huni Sandstone. The conglomeratic units of the Tarkwaian Group is interpreted as having been deposited in alluvial fans and then reworked by braided stream channels (Griffis et al. 2002). The latter is thought to have concentrated fine particles of gold within the channel conglomerates. The Tarkwaian is folded along the north-eastern axis which enhances the groundwater potential (Kesse 1985). Moreover, according to the CSIR-WRI Database (2007), the Birimian and Tarkwaian formations of the area are marked with extensive weathering, availability of quartz vein and the presence of buried river channel (Dickson and Benneh 1980) as contributory factors to promote groundwater potential in the terrain (Kortatsi 1994).

\section{Methodology}

The data for this study were taken from the Regional Office of community water and sanitation Agency, Cape Coast. The data were taken by qualified professionals who observed the appropriate protocols to ensure the accuracy of data. Originally the data were taken under a project aimed to supply 
water to some selected communities within the districts. The data were taken Abeam Terrameter which principle of operation is the determination of subsurface resistivity variation with depth by the measurement of the resistance of the various lithologies for the generation of the apparent resistivity of the lithologies. A total of 37 VES points were probed in the study area using the symmetrical Schlumberger electrode spread technique with maximum electrode spacing $(\mathrm{AB} / 2)$ of $100 \mathrm{~m}$. The resistance recorded from the machine at each point was multiplied by the geometric factor $k$ for the electrode separation to get the apparent resistivity. The apparent resistivity values were plotted against $A B / 2$ on logarithmic forms for the preview of the aquifer characterization and noise minimization by the repetition of measurements until acceptable readings were obtained at a standard deviation in the order of $10^{-2 \%}$ as the curves were interpreted by partial curve matching technique. The geoelectric parameters from the partial curve matching served as the input model for computer-assisted iteration using WINRESIST. The existing boreholes in the study area were calibrated to assess the groundwater potential at the local hydrogeological unit and thereby estimate the success rate of the drilling program. Longitudinal conductance of the overburden rock units was used to evaluation of aquifer protective capacity. The longitudinal unit conductance gives a measure of the impermeability of the confining clay layer, which has low resistivity and low hydraulic conductivity. The longitudinal layer conductance $(\mathrm{S})$ of the overburden at each station was obtained from Eq. (1)

$S=\sum_{i=1}^{n} \frac{h_{i}}{\rho_{i}}$

where $S$ is the total longitudinal conductance, $\Sigma$ is summation sign, $h_{i}$ is the thickness of the $i$ th layer and $\rho_{i}$ is the resistivity of the $i$ th layer (Henriet 1976).

The reflection coefficients $(r)$ of the study area were calculated using Eq. (2) below.

$r=\left(\frac{\rho n-\rho(n-1)}{\rho n+\rho(n-1)}\right)$

where $r$ is the reflection coefficient, $\rho_{n}$ is the layer resistivity of the $n$th layer, $\rho(n-1)$ is the layer resistivity overlying the $n$th layer (Bhattacharya and Patra 1968; Loke 1999).

\section{Results and discussion}

The use of the geoelectrical resistivity method in groundwater studies including the assessment of groundwater potential and the aquifer protective capabilities is well documented in the literature (Golam et al. 2014; Keller and Frischknecht
1966; Koefoed 1979; Olorunfemi et al. 1998; Henriet 1976). Table 1 gives a summary of the geoelectric parameters of the study area. The characteristic curves include KH (17), HKH (3), K (1), KHKQ (1), KQ (1), KQH (2) QHK (1), KHKH (1), KHK (1), QH (1), KHA (2), AA (1), HA (1), A (1), AKH (3). The study revealed three-to-six layers with an average of four (4) layers according to the geophysical analysis of the weathered overburden zone in the formation including laterite $(0.34-3.57 \mathrm{~m})$; clay $(0.64-8.84 \mathrm{~m})$; sandy-clay (0.67-27.09 m) and slightly to highly weathered bedrock which includes phyllites and granite $(3.09-86.89 \mathrm{~m})$ which reveals a high level of heterogeneity of electrical resistivity of the geologic materials within the study area and the weathered layers serve as the aquiferous zones. The abundance of the four-layer lithologies, especially in the Birimian formation, agrees with the observation of Okrah et al. (2012), .

\section{Groundwater potential of the study area}

According to Okrah et al. (2012), the geophysical interpretation of the Tarkwaian formation of the study area shows that it consists of four layers of sandy-clay, laterite, weathered phyllite and granite and the aquiferous zone located in the third or fourth layer with a characteristic average resistivity of $415.05 \Omega \mathrm{m}$, borehole located at $122-148 \mathrm{~m}$ above mean sea level, average resistivity and thickness of the overburden rocks being $491.82 \Omega \mathrm{m}$ and $2.38 \mathrm{~m}$, respectively, while the depth of the borehole ranges between 40.0 and $75.0 \mathrm{~m}$ with an average of $55.0 \mathrm{~m}$. The first layer consists of an average $3 \mathrm{~m}$ sandy-clay and laterite patches; the bedrock is phyllite and granite buried within the ranges of 3-24 m with an average of $16 \mathrm{~m}$ deep and shows different degrees of weathering at different locations. The average potential yield of a borehole is $19 \mathrm{~L} / \mathrm{min}$ ranging between 12 and $30 \mathrm{~L} / \mathrm{min}$. CSIR-WRI Database (1996) recorded depths to aquifer range of 6-69 m with a mean of $37 \mathrm{~m}$, Coffey (2007) reported a range of 13-60 m, while CAGL (2010) reported a range of 6-92 m with a mean of $22.4 \mathrm{~m}$. This reveals the presence of both shallow and deep-seated aquifers in the study area. The Birimian is characterized by structural features such as welldeveloped joint and fracture systems as well as quartz veins within the phyllite bodies. These structural features, as well as the extent of weathering, determine groundwater occurrence in the Birimian system. The best aquifers are located where significantly decomposed materials have been accumulated, which are usually along the slopes of the synclinal troughs (Dapaah-Siakwan and Gyau-Boakye 2000). The predominantly argillaceous sediments have metamorphosed into schist, slate, phyllite and greywacke. The tuff and lava range from mafic to silicic composition with many of the mafic extruded underwater. The contact between the saprolite and

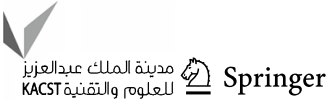


Table 1 Summary of the geoelectric parameters of the study area

\begin{tabular}{|c|c|c|c|c|c|c|c|}
\hline Community & VES station & Layer & Depth (m) & Thickness (m) & App. resistivity $(\Omega-\mathrm{m})$ & Curve characteristics & Curve type \\
\hline \multirow[t]{17}{*}{ Akwaboso } & \multirow[t]{4}{*}{ A60 } & 1 & 0.96 & 0.96 & 80 & \multirow[t]{4}{*}{$\mathrm{P} 1<\mathrm{P} 2>\mathrm{P} 3<\mathrm{P} 4$} & \multirow[t]{4}{*}{ KH } \\
\hline & & 2 & 9.80 & 8.84 & 233 & & \\
\hline & & 3 & 84.2 & 74.4 & 9 & & \\
\hline & & 4 & - & & 410 & & \\
\hline & \multirow[t]{5}{*}{ A140 } & 1 & 0.34 & 0.34 & 2043 & \multirow[t]{5}{*}{$\mathrm{P} 1>\mathrm{P} 2<\mathrm{P} 3>\mathrm{P} 4<\mathrm{P} 5$} & \multirow[t]{5}{*}{ HKH } \\
\hline & & 2 & 1.81 & 1.47 & 111 & & \\
\hline & & 3 & 2.48 & 0.67 & 4069 & & \\
\hline & & 4 & 83.0 & 80.52 & 9 & & \\
\hline & & 5 & - & & 410 & & \\
\hline & \multirow[t]{4}{*}{ B78 } & 1 & 0.72 & 0.72 & 39 & \multirow[t]{4}{*}{$\mathrm{P} 1<\mathrm{P} 2>\mathrm{P} 3<\mathrm{P} 4$} & \multirow[t]{4}{*}{ KH } \\
\hline & & 2 & 1.91 & 1.19 & 2720 & & \\
\hline & & 3 & 88.8 & 86.89 & 26 & & \\
\hline & & 4 & - & & 284 & & \\
\hline & \multirow[t]{4}{*}{ A182 } & 1 & 3.57 & 3.57 & 304 & \multirow[t]{4}{*}{$\mathrm{P} 1<\mathrm{P} 2>\mathrm{P} 3<\mathrm{P} 4$} & \multirow[t]{4}{*}{ KH } \\
\hline & & 2 & 8.25 & 4.68 & 1080 & & \\
\hline & & 3 & 30.9 & 22.65 & 10 & & \\
\hline & & 4 & - & & 539 & & \\
\hline \multirow[t]{13}{*}{ Efiefiso } & \multirow[t]{3}{*}{ D78 } & 1 & 1.28 & 1.28 & 517 & \multirow[t]{3}{*}{$\mathrm{P} 1<\mathrm{P} 2>\mathrm{P} 3$} & \multirow[t]{3}{*}{ K } \\
\hline & & 2 & 16.2 & 14.92 & 1017 & & \\
\hline & & 3 & - & & 161 & & \\
\hline & \multirow[t]{6}{*}{ Existing BH } & 1 & 0.71 & 0.71 & 220 & \multirow[t]{6}{*}{$\mathrm{P} 1<\mathrm{P} 2>\mathrm{P} 3<\mathrm{P} 4>\mathrm{P} 5>\mathrm{P} 6$} & \multirow[t]{6}{*}{ KHKQ } \\
\hline & & 2 & 1.47 & 0.76 & 1327 & & \\
\hline & & 3 & 3.07 & 1.6 & 181 & & \\
\hline & & 4 & 6.16 & 3.09 & 815 & & \\
\hline & & 5 & 52.0 & 45.84 & 166 & & \\
\hline & & 6 & - & & 4.76 & & \\
\hline & \multirow[t]{4}{*}{ C52 } & 1 & 1.19 & 1.19 & 82 & $\mathrm{P} 1<\mathrm{P} 2>\mathrm{P} 3<\mathrm{P} 4$ & KH \\
\hline & & 2 & 4.81 & 3.62 & 390 & & \\
\hline & & 3 & 16.3 & 11.49 & 141 & & \\
\hline & & 4 & - & & 737 & & \\
\hline Dominase & C188 & 1 & 1.16 & 1.16 & 80 & $\mathrm{P} 1<\mathrm{P} 2>\mathrm{P} 3<\mathrm{P} 4$ & KH \\
\hline & & 2 & 3.34 & 2.18 & 652 & & \\
\hline & & 3 & 9.54 & 6.2 & 23 & & \\
\hline & & 4 & - & & 40 & & \\
\hline & $\mathrm{B} 50$ & 1 & 0.43 & 0.43 & 305 & $\mathrm{P} 1<\mathrm{P} 2>\mathrm{P} 3>\mathrm{P} 4$ & KQ \\
\hline & & 2 & 1.07 & 0.64 & 2983 & & \\
\hline & & 3 & 7.52 & 6.45 & 237 & & \\
\hline & & 4 & - & & 54 & & \\
\hline & B76 & 1 & 1.21 & 1.21 & 570 & $\mathrm{P} 1<\mathrm{P} 2>\mathrm{P} 3>\mathrm{P} 4<\mathrm{P} 5$ & $\mathrm{KQH}$ \\
\hline & & 2 & 2.27 & 1.06 & 2991 & & \\
\hline & & 3 & 9.59 & 7.32 & 107 & & \\
\hline & & 4 & 40.3 & 30.71 & 35 & & \\
\hline & & 5 & - & & 2751 & & \\
\hline & Existing $\mathrm{BH}$ & 1 & 1.06 & 1.06 & 20 & $\mathrm{P} 1<\mathrm{P} 2>\mathrm{P} 3<\mathrm{P} 4$ & KH \\
\hline & & 2 & 3.55 & 2.49 & 98 & & \\
\hline & & 3 & 6.92 & 3.37 & 13 & & \\
\hline & & 4 & - & & 104 & & \\
\hline
\end{tabular}


Table 1 (continued)

\begin{tabular}{|c|c|c|c|c|c|c|c|}
\hline Community & VES station & Layer & Depth (m) & Thickness (m) & App. resistivity $(\Omega-\mathrm{m})$ & Curve characteristics & Curve type \\
\hline & \multirow[t]{4}{*}{ B145 } & 1 & 0.57 & 0.57 & 12 & \multirow[t]{4}{*}{$\mathrm{P} 1<\mathrm{P} 2>\mathrm{P} 3<\mathrm{P} 4$} & \multirow[t]{4}{*}{ KH } \\
\hline & & 2 & 1.75 & 1.18 & 1002 & & \\
\hline & & 3 & 6.52 & 4.77 & 4 & & \\
\hline & & 4 & - & & 143 & & \\
\hline & \multirow[t]{4}{*}{$\mathrm{C} 150$} & 1 & 1.41 & 1.41 & 105 & \multirow[t]{4}{*}{$\mathrm{P} 1<\mathrm{P} 2>\mathrm{P} 3<\mathrm{P} 4$} & \multirow[t]{4}{*}{$\mathrm{KH}$} \\
\hline & & 2 & 4.35 & 2.94 & 1154 & & \\
\hline & & 3 & 26.6 & 22.25 & 16 & & \\
\hline & & 4 & - & & 4432 & & \\
\hline & \multirow[t]{4}{*}{ A130 } & 1 & 0.43 & 0.43 & 130 & \multirow[t]{4}{*}{$\mathrm{P} 1<\mathrm{P} 2>\mathrm{P} 3<\mathrm{P} 4$} & \multirow[t]{4}{*}{ KH } \\
\hline & & 2 & 4.61 & 4.18 & 569 & & \\
\hline & & 3 & 31.7 & 27.09 & 23 & & \\
\hline & & 4 & - & & 5507 & & \\
\hline & \multirow[t]{4}{*}{ A88 } & 1 & 0.56 & 0.56 & 24 & \multirow[t]{4}{*}{$\mathrm{P} 1<\mathrm{P} 2>\mathrm{P} 3<\mathrm{P} 4$} & \multirow[t]{4}{*}{$\mathrm{KH}$} \\
\hline & & 2 & 6.53 & 5.97 & 153 & & \\
\hline & & 3 & 17.7 & 11.17 & 8 & & \\
\hline & & 4 & - & & 4231 & & \\
\hline & \multirow[t]{4}{*}{$\mathrm{C} 80$} & 1 & 3.30 & 3.30 & 74 & \multirow[t]{4}{*}{$\mathrm{P} 1<\mathrm{P} 2>\mathrm{P} 3<\mathrm{P} 4$} & \multirow[t]{4}{*}{ KH } \\
\hline & & 2 & 7.72 & 4.42 & 356 & & \\
\hline & & 3 & 23.5 & 15.78 & 14 & & \\
\hline & & 4 & - & & 5668 & & \\
\hline \multirow[t]{25}{*}{ Kwameprakrom } & \multirow[t]{5}{*}{ A168 } & 1 & 1.61 & 1.61 & 741 & \multirow[t]{5}{*}{$\mathrm{P}>\mathrm{P}>\mathrm{P}<\mathrm{P}>\mathrm{P}$} & \multirow[t]{5}{*}{ QHK } \\
\hline & & 2 & 7.99 & 6.38 & 64 & & \\
\hline & & 3 & 16.6 & 8.61 & 15 & & \\
\hline & & 4 & 25.8 & 9.2 & 88 & & \\
\hline & & 5 & - & & 17 & & \\
\hline & \multirow[t]{6}{*}{ A52 } & 1 & 0.43 & 0.43 & 253 & \multirow[t]{6}{*}{$\mathrm{P}<\mathrm{P}>\mathrm{P}<\mathrm{P}>\mathrm{P}<\mathrm{P}$} & \multirow[t]{6}{*}{ KHKH } \\
\hline & & 2 & 1.50 & 1.07 & 637 & & \\
\hline & & 3 & 2.67 & 1.17 & 8 & & \\
\hline & & 4 & 7.02 & 4.35 & 100 & & \\
\hline & & 5 & 29.4 & 22.38 & 22 & & \\
\hline & & 6 & - & & 54 & & \\
\hline & C62 & 1 & 1.81 & 1.81 & 54 & $\mathrm{P}<\mathrm{P}>\mathrm{P}<\mathrm{P}>\mathrm{P}$ & KHK \\
\hline & & 2 & 3.50 & 1.69 & 766 & & \\
\hline & & 3 & 8.30 & 4.8 & 38 & & \\
\hline & & 4 & 18.1 & 9.8 & 502 & & \\
\hline & & 5 & - & & 31 & & \\
\hline & A142 & 1 & 1.69 & 1.69 & 543 & $\mathrm{P}>\mathrm{P}>\mathrm{P}<\mathrm{P}$ & QH \\
\hline & & 2 & 8.10 & 6.41 & 58 & & \\
\hline & & 3 & 10.7 & 2.6 & 15 & & \\
\hline & & 4 & - & & 37 & & \\
\hline & B75 & 1 & 0.47 & 0.47 & 263 & $\mathrm{P}<\mathrm{P}>\mathrm{P}>\mathrm{P}<\mathrm{P}$ & $\mathrm{KQH}$ \\
\hline & & 2 & 1.40 & 0.93 & 1344 & & \\
\hline & & 3 & 7.14 & 5.74 & 118 & & \\
\hline & & 4 & 12.2 & 5.06 & 12 & & \\
\hline & & 5 & - & & 39 & & \\
\hline
\end{tabular}


Table 1 (continued)

\begin{tabular}{|c|c|c|c|c|c|c|c|}
\hline Community & VES station & Layer & Depth (m) & Thickness (m) & App. resistivity $(\Omega-\mathrm{m})$ & Curve characteristics & Curve type \\
\hline & A100 & 1 & 0.46 & 0.46 & 41 & $\mathrm{P}<\mathrm{P}>\mathrm{P}<\mathrm{P}<\mathrm{P}$ & KHA \\
\hline & & 2 & 1.58 & 1.12 & 634 & & \\
\hline & & 3 & 3.48 & 1.9 & 4 & & \\
\hline & & 4 & 83 & 79.52 & 45 & & \\
\hline & & 5 & - & & 90 & & \\
\hline \multirow[t]{5}{*}{ Agyiempaboa } & $\mathrm{C} 115$ & 1 & 0.53 & 0.53 & 173 & $\mathrm{P}>\mathrm{P}<\mathrm{P}>\mathrm{P}<\mathrm{P}$ & $\mathrm{HKH}$ \\
\hline & & 2 & 1.41 & 0.88 & 39 & & \\
\hline & & 3 & 4.53 & 3.12 & 1184 & & \\
\hline & & 4 & 32.8 & 28.27 & 58 & & \\
\hline & & 5 & - & & 3940 & & \\
\hline \multirow[t]{16}{*}{ Akropong } & C65 & 1 & 0.61 & 0.61 & 74 & $\mathrm{P}<\mathrm{P}<\mathrm{P}<\mathrm{P}$ & $\mathrm{AA}$ \\
\hline & & 2 & 2.92 & 2.31 & 157 & & \\
\hline & & 3 & 30.1 & 27.18 & 381 & & \\
\hline & & 4 & - & & 8750 & & \\
\hline & D98 & 1 & 1.60 & 1.60 & 15 & $\mathrm{P}<\mathrm{P}>\mathrm{P}<\mathrm{P}$ & $\mathrm{KH}$ \\
\hline & & 2 & 14.3 & 12.7 & 22,261 & & \\
\hline & & 3 & 43.6 & 29.3 & 622 & & \\
\hline & & 4 & - & & 21,889 & & \\
\hline & D42 & 1 & 4.67 & 4.67 & 40 & $\mathrm{P}<\mathrm{P}>\mathrm{P}<\mathrm{P}$ & $\mathrm{KH}$ \\
\hline & & 2 & 27.1 & 22.43 & 98,100 & & \\
\hline & & 3 & 38.7 & 11.6 & 491 & & \\
\hline & & 4 & - & & 21,889 & & \\
\hline & C115 & 1 & 0.40 & 0.40 & 829 & $\mathrm{P}>\mathrm{P}<\mathrm{P}<\mathrm{P}$ & HA \\
\hline & & 2 & 6.55 & 6.15 & 112 & & \\
\hline & & 3 & 25.2 & 18.65 & 268 & & \\
\hline & & 4 & - & & 75,845 & & \\
\hline \multirow[t]{16}{*}{ Adwumam } & A172 & 1 & 0.49 & 0.49 & 15 & $\mathrm{P}<\mathrm{P}>\mathrm{P}<\mathrm{P}$ & $\mathrm{KH}$ \\
\hline & & 2 & 0.77 & 0.28 & 5609 & & \\
\hline & & 3 & 25.8 & 25.03 & 241 & & \\
\hline & & 4 & - & & 21,889 & & \\
\hline & $\mathrm{B} 60$ & 1 & 2.44 & 2.44 & 57 & $\mathrm{P}<\mathrm{P}<\mathrm{P}$ & $\mathrm{A}$ \\
\hline & & 2 & 21.6 & 19.16 & 235 & & \\
\hline & & 3 & - & & 52,660 & & \\
\hline & A95 & 1 & 1.97 & 1.97 & 432 & $\mathrm{P}<\mathrm{P}>\mathrm{P}<\mathrm{P}<\mathrm{P}$ & KHA \\
\hline & & 2 & 3.79 & 1.82 & 1442 & & \\
\hline & & 3 & 9.53 & 5.74 & 512 & & \\
\hline & & 4 & 52.7 & 43.17 & 2043 & & \\
\hline & & 5 & - & & 48,529 & & \\
\hline & A130 & 1 & 0.63 & 0.63 & 78 & $\mathrm{P}<\mathrm{P}>\mathrm{P}<\mathrm{P}$ & $\mathrm{KH}$ \\
\hline & & 2 & 4.44 & 3.81 & 1508 & & \\
\hline & & 3 & 23.5 & 19.06 & 733 & & \\
\hline & & 4 & - & & 290,000 & & \\
\hline
\end{tabular}


Table 1 (continued)

\begin{tabular}{|c|c|c|c|c|c|c|c|}
\hline Community & VES station & Layer & Depth (m) & Thickness (m) & App. resistivity $(\Omega-m)$ & Curve characteristics & Curve type \\
\hline \multirow[t]{28}{*}{ Buaben } & \multirow[t]{4}{*}{ A 42} & 1 & 1.89 & 1.89 & 37 & \multirow[t]{4}{*}{$\mathrm{P}<\mathrm{P}>\mathrm{P}<\mathrm{P}$} & \multirow[t]{4}{*}{ KH } \\
\hline & & 2 & 5.27 & 3.38 & 10,448 & & \\
\hline & & 3 & 56.6 & 51.33 & 479 & & \\
\hline & & 4 & - & & 1898 & & \\
\hline & \multirow[t]{4}{*}{ B112 } & 1 & 1.87 & 1.87 & 170 & \multirow[t]{4}{*}{$\mathrm{P}<\mathrm{P}>\mathrm{P}<\mathrm{P}$} & \multirow[t]{4}{*}{ KH } \\
\hline & & 2 & 4.09 & 2.22 & 6423 & & \\
\hline & & 3 & 27.8 & 23.71 & 530 & & \\
\hline & & 4 & - & & 34,546 & & \\
\hline & \multirow[t]{5}{*}{ A240 } & 1 & 1.00 & 1.00 & 410 & \multirow[t]{5}{*}{$\mathrm{P}<\mathrm{P}<\mathrm{P}>\mathrm{P}<\mathrm{P}$} & \multirow[t]{5}{*}{$\mathrm{AKH}$} \\
\hline & & 2 & 8.14 & 7.14 & 1003 & & \\
\hline & & 3 & 15.1 & 6.96 & 2060 & & \\
\hline & & 4 & 34.4 & 19.3 & 376 & & \\
\hline & & 5 & - & & 94,881 & & \\
\hline & \multirow[t]{5}{*}{ A110 } & 1 & 0.31 & 0.31 & 6122 & \multirow{5}{*}{$\mathrm{P}>\mathrm{P}<\mathrm{P}>\mathrm{P}<\mathrm{P}$} & \multirow[t]{5}{*}{$\mathrm{HKH}$} \\
\hline & & 2 & 1.11 & 0.8 & 98 & & \\
\hline & & 3 & 2.37 & 1.26 & 6052 & & \\
\hline & & 4 & 33.3 & 30.93 & 603 & & \\
\hline & & 5 & - & & 130,000 & & \\
\hline & \multirow[t]{5}{*}{ Existing BH (304 BU1) } & 1 & 0.66 & 0.66 & 152 & \multirow[t]{5}{*}{$\mathrm{P}<\mathrm{P}<\mathrm{P}>\mathrm{P}<\mathrm{P}$} & \multirow[t]{5}{*}{$\mathrm{AKH}$} \\
\hline & & 2 & 4.78 & 4.12 & 280 & & \\
\hline & & 3 & 7.02 & 2.24 & 3312 & & \\
\hline & & 4 & 83 & 75.98 & 1333 & & \\
\hline & & 5 & - & & 27,753 & & \\
\hline & \multirow[t]{5}{*}{ B68 } & 1 & 0.90 & 0.90 & 15 & \multirow[t]{5}{*}{$\mathrm{P}<\mathrm{P}<\mathrm{P}>\mathrm{P}<\mathrm{P}$} & \multirow[t]{5}{*}{$\mathrm{AKH}$} \\
\hline & & 2 & 3.19 & 2.29 & 97 & & \\
\hline & & 3 & 4.87 & 1.68 & 100,000 & & \\
\hline & & 4 & 77.7 & 72.83 & 12,723 & & \\
\hline & & 5 & - & & $1,100,000$ & & \\
\hline
\end{tabular}

the saprock is the most productive groundwater zone within the Birimian system as they usually complement each other in terms of permeability and storage (Carrier et al. 2008a, b). The fracture systems within the granitoids are localized with overlying porous weathered profiles serving as a storage reservoir. Dapaah-Siakwan and Gyau-Boakye (2000) upon analysis of borehole data in Ghana concluded that the mean depth of boreholes in the Lower Birimian rocks and the associated granites was $35 \mathrm{~m}$ and $60 \mathrm{~m}$, respectively. They estimated the yield of boreholes in the Birimian to be about $212 \mathrm{l} / \mathrm{min}\left(12.7 \mathrm{~m}^{3} / \mathrm{h}\right)$. Bayewu et al. (2018) observed that the use of the thickness of overburden rocks and the reflection coefficient is good in estimating the groundwater potential in a typical basement terrain.

In this study, thirty-seven potential points selected after the horizontal profiling were probed by using the Schlumberger technique for the determination of the vertical variation of rock resistivity with depth to identify the thickness of the regolith and possible aquiferous zone.

Existing boreholes were added to the selected points for calibration as evidence of the hydrogeological conditions of the study area. Groundwater potential of the area was classified as high, medium and low regarding the overburden thickness and reflection coefficient values. The study revealed that the areas of highest groundwater yield are characterized 
by thick overburden ( $>13 \mathrm{~m}$ ) overlying the fractured zone which showed low reflection coefficients $(r<0.8)$. About $21.6 \%$ showed a high groundwater potential. When the overburden rock is thick $(>13 \mathrm{~m})$ and the reflection coefficient is high $(r>0.8)$ the area is said to have medium groundwater potential and $62.2 \%$ of the total VES points were found in this category. An area of thin layer and high reflection coefficient shows low potential, while an area of thin layer and low reflection coefficient shows very low potential. The study shows that about $2.7 \%$ and $13.5 \%$ of the VES points have low and very low potentials, respectively, which agrees with the previous studies of the area. Spatially, the thickness of the overburden rocks is higher in the northernmost and the south-eastern corner of the study area, while the lowest is seen close to the center of the study area (Fig. 2a). However, the reflective coefficient of the study area is higher at the western and southern parts of the study area (Fig. 2b). The point that shows the lowest overburden also shows a lower reflective coefficient. The point is underlain by a granitic intrusion (Fig. 1) which is the cause of such occurrences. To display the spatial variation of groundwater potential of the study area, numerical weight was assigned to the various rating as shown in Table 2. Based on the weight assigned to the various potential yields, a thematic map of the groundwater potential of the study area was generated (Fig. 2c) which reveals that the groundwater potential is higher at the western and south-eastern corner of the study area.

The western side of the study area is mainly underlain by the Birimian, while the south-eastern corner is underlain by the Tarkwaian indicating that the two formations have similar groundwater potential in the study area. The point of lowest groundwater potential is the point underlain by the granitic intrusion. The observations in this study agree with that of previous studies. According to previous studies, phyllite is the major rock type of the Birimian and the Tarkwaian formations which underlain the study area which is strongly foliated, fractured, weathered, contains quartz vein, the possible presence of buried river channel which has a relatively rich aquifer of $0.3-250 \mathrm{~L} / \mathrm{min}$ borehole yield with an average yield of $12.7 \mathrm{~L} / \mathrm{min}$, a success rate of $75 \%$, borehole depth of 34-60 m with an average of $53 \mathrm{~m}$, hence, drilling to the right depth results to borehole success (Wyllie 1963; Kesse 1985; Dickson and Benneh 1980; Kortatsi 1994; Dapaah-Siakwan and Gyau-Boakye 2000; CSIR-WRI Database 2007; Okrah et al. 2012). Some studies and available data have suggested the yield of 4-250 L/min, 5.0-7.0 L/min which still supports the high groundwater potential of the study area (GSD 2012; Okrah et al. 2012). The undulating topography influences the thickness which controls the aquifer horizon at any site in the study area. Okrah et al. (2012) observed laterite, clay, sandyclay and bedrocks made of partly weathered or fresh phyllite and granite in the Birimian environment. They reported on $100 \%$ borehole drilling success rate with a drilling yield range of 12.0-60.0 L/ min and an average depth of successful boreholes of $38.8 \mathrm{~m}$ within the study area and comparison of the geophysical analysis and the borehole drilling logs (Table 3) revealed that the number of layers obtained from the geophysical analysis was not the same as those obtained from the drilling logs and they attributed this occurrence to the ambiguities existing among the adjoining beds. However, they observed that the aquiferous horizons predicted from the geophysical interpretation were confirmed by the water-bearing zone shown by the logs (Table 4) indicating the appropriateness of the use of the geophysical technique to generally present adequate information on the subsurface condition useful for resources exploration. CSIR-WRI (1996) recorded a borehole yield range of 10.0-136.7 L/min with an average of $45.0 \mathrm{~L} / \mathrm{min}$, while Coffey (2007) recorded a borehole yield range of 11.7-179.8 L/min with a mean of $45 \mathrm{~L} / \mathrm{min}$. This reveals that the average borehole yield of the study area is around $45 \mathrm{~L} / \mathrm{min}$. Coffey (2007) reported that the aquifers of the study area have a limited areal extent, low storage capacity, a transmissivity range of $1.7-3.7 \mathrm{~m}^{2} /$ day and an average of $2.98 \mathrm{~m}^{2} /$ day. He also recorded a static water level range of $1.7-23.3 \mathrm{~m}$ with a mean of $9.16 \mathrm{~m}$, while CAGL (2010) recorded a range of 1.7-26.6 $\mathrm{m}$ with a mean of $12.62 \mathrm{~m}$ in the inclined holes.

\section{Aquifer protective capacity evaluation}

In the absence of an impermeable overlying layer such as clay, the aquifer becomes vulnerable to the inflow of contaminated fluid. Naturally, the earth materials filter contaminated fluids as they percolate through them to the groundwater and this defines their protective capacity which can be assessed by the geoelectrical method (Olorunfemi et al. 1998). The assessment of aquifer protective capability depends on the natural laws by which the environment protects the groundwater from surface contamination to some degree through filtration. Henriet (1976) showed that the longitudinal conductance $(S)$ can be used to evaluate the hydrologic properties of an aquifer and the protective capacity of an overburden rock is considered to be proportional to the longitudinal unit conductance in mhos (Olorunfemi et al. 1998). Due to the large-scale mining, illegal small-scale mining ('galamsey') and farming activities that are common in the study area the groundwater can easily be contaminated and consequently pollute the whole aquifer system within the catchment area, and hence, there is a need to assess the capability of the rocks to prevent such contaminations from mining, farming and other anthropogenic sources. The longitudinal conductance was evaluated from the thickness and resistivity values of the various geoelectric layers, and the values were used in the classification of the aquifer protective capacity of the VES locations. Impervious materials 
show high longitudinal conductance values as a result of their low resistivity values, while permeable ones have low longitudinal conductance values due to their high resistivity values. High longitudinal conductance values indicate excellent aquifer protective capacity, while low values reveal poor protective capacity. The longitudinal unit conductance values which reveal very good to poor capacities of the overburden materials in the study area are shown in Table 5 . The various VES points showed the capacities as very good (5\%), good (27\%), moderate (19\%), and weak (22\%) and poor $(27 \%)$. High longitudinal conductance indicates

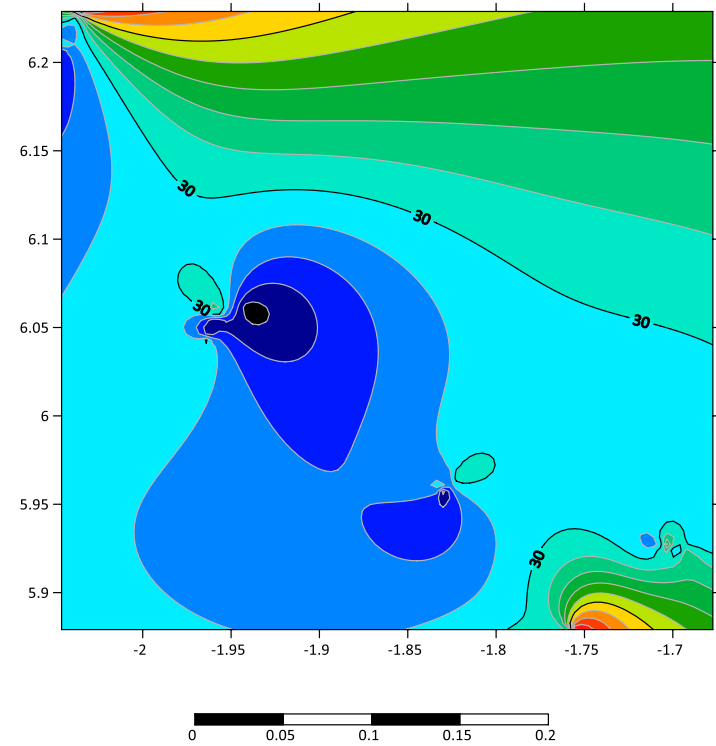

(a)

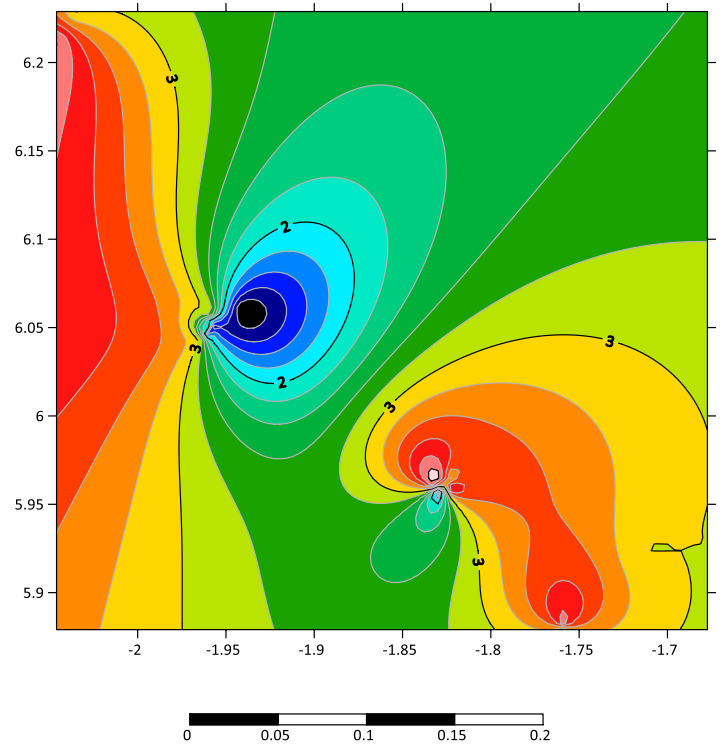

(c) relatively high protective capacity of the overburden rocks. The areas of weak and poor aquifer protective capacities are potential zones of high infiltration rates from liquid from the surface; hence, they are areas vulnerable to leachate and other surface contaminants. The study reveals that generally, the overburden layer can protect the groundwater system from infiltration of fluid contaminants. However, there were weak and poor zones that can serve as vulnerable zones for contamination. These poor zones revealed areas of thin overburden rocks and high electrical resistivities. The variation in the aquifer protective capacities within the study
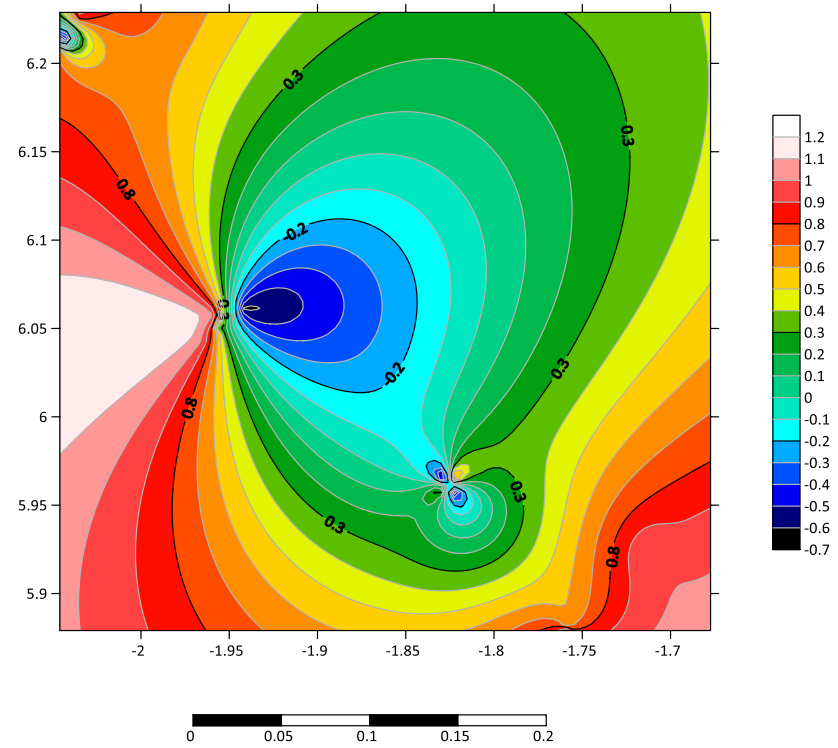

(b)

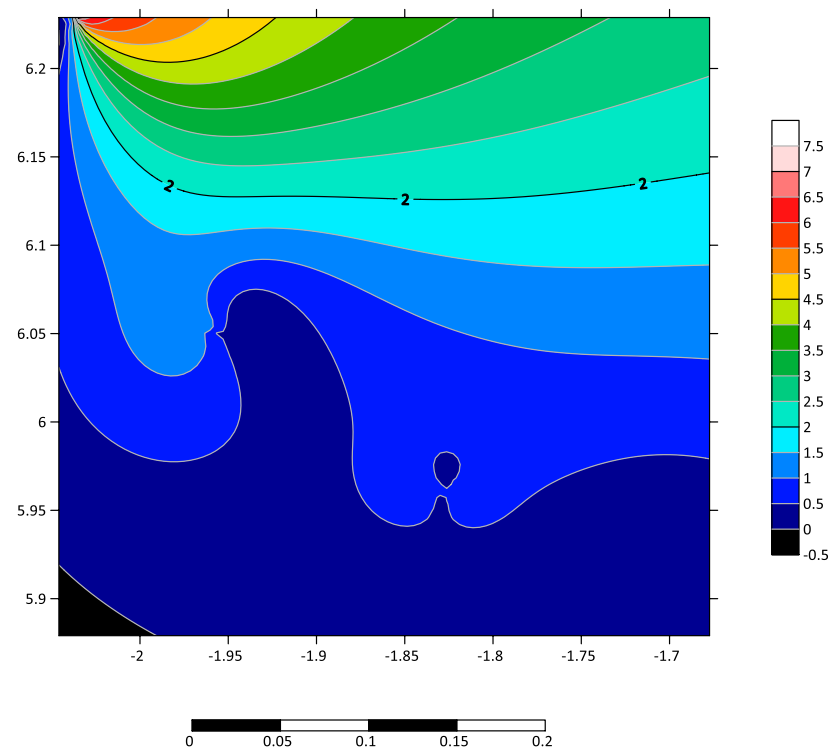

(d)

Fig. 2 Thematic map showing the spatial distribution of $\mathbf{a}$ overburden thickness and $\mathbf{b}$ reflective coefficient, $\mathbf{c}$ groundwater potential yield rating and $\mathbf{d}$ longitudinal unit conductance in the study area 
area agrees with the observation of Okrah et al. (2012) that the rock formation in the study area is highly anisotropic with varying petrophysical properties like the attitude of the bedding plane, texture, sorted grains, pore size and interconnection between pores or fractures which are influenced by agents such as weathering, sedimentation, compaction or crystallization to define the characterization of the formation which calls for a careful selection appropriate geophysical technique to be employed for a successful groundwater investigation. The spatial variation of the aquifer protective capacity of the area is shown in Fig. 2d. The higher capacity values are seen in the north-western corner of the study area, while the lowest values are seen in the south-western corner of the area. The Tarkwaian formation shows poorer aquifer protective capacity as compare to the Birimian formation. It is, therefore, important for the groundwater resources to

Table 2 Numerical weight of groundwater potential yields

\begin{tabular}{ll}
\hline $\begin{array}{l}\text { Groundwater poten- } \\
\text { tial yield }\end{array}$ & $\begin{array}{l}\text { Numeri- } \\
\text { cal } \\
\text { weight }\end{array}$ \\
\hline Very low & 1 \\
Low & 2 \\
Medium & 3 \\
High & 4 \\
\hline
\end{tabular}

be protected from surface contaminates in the study area, especially in the Tarkwaian formation.

\section{Conclusion}

After extensive geophysical exploration for groundwater within the study area, the predictions were validated from previous studies. The study revealed that the characteristic curves include KH (17), HKH (3), K (1), KHKQ (1), KQ (1), KQH (2) QHK (1), KHKH (1), KHK (1), QH (1), KHA (2), AA (1), HA (1), A (1), AKH (3). The study revealed three-to-six layers with an average of four (4) layers according to the geophysical analysis of the weathered overburden zone in the formation including laterite $(0.34-3.57 \mathrm{~m})$; clay (0.64-8.84 m); sandy-clay (0.67-27.09 m) and slightly to highly weathered bedrock which includes phyllites and granite (3.09-86.89 m) which reveals a high level of heterogeneity of electrical resistivity of the geologic materials within the study area. The weathered layers serve as the aquiferous zones. About 21.6\%, 62.2\%, 2.7\% and 13.5\% showed high, medium, low and very low potentials for groundwater, respectively, with higher groundwater potentials at the western and south-eastern corner of the study area underlain by the Birimian and Tarkwaian formations, respectively, indicating that the two formations have similar groundwater potentials in the study area. The lowest groundwater potential was observed at the point underlain by a granitic

Table 3 Comparison between drilling and geophysical results (Okrah et al. 2012)

\begin{tabular}{|c|c|c|c|c|c|c|c|c|}
\hline \multirow[t]{3}{*}{ Community } & \multirow[t]{3}{*}{ VES point } & \multicolumn{2}{|l|}{ No of layers } & \multicolumn{3}{|c|}{ Depth to bedrock (m) } & \multicolumn{2}{|l|}{ Aquifer horizon (m) } \\
\hline & & \multirow{2}{*}{$\begin{array}{l}\text { Geophysical } \\
\text { interpret }\end{array}$} & \multirow{2}{*}{$\begin{array}{l}\text { Borehole } \\
\text { drilling }\end{array}$} & \multirow{2}{*}{$\begin{array}{l}\text { Geophysical } \\
\text { interpretation }\end{array}$} & \multicolumn{2}{|c|}{ Borehole drilling } & \multirow{2}{*}{$\begin{array}{l}\text { Geophysical inter- } \\
\text { pretation (estimated) }\end{array}$} & \multirow[t]{2}{*}{ Borehole drilling } \\
\hline & & & & & weathered & Hammed & & \\
\hline \multirow[t]{2}{*}{ Buabinso } & B30 & 3 & 4 & 2.7 & 18.0 & Deep-seated & $40.0-50.0$ & $25.0-36.0$ \\
\hline & $\mathrm{C} 100$ & 4 & 4 & 0.7 & 3.0 & 7.0 & $20.0-40.0$ & $32.0-39.0$ \\
\hline Congo No.1 & B80 & 3 & 5 & 42.8 & 18.0 & Deep-seated & $15.0-40.0$ & $17.0-23.0$ \\
\hline Zion No.1 & A40 & 3 & 4 & 27.9 & 24.0 & 33.0 & $40.0-60.0$ & $31.0-40.0$ \\
\hline Achiase & B100 & 4 & 5 & 3.0 & 7.0 & 19.0 & 10.4-extended & $20.0-38.0$ \\
\hline
\end{tabular}

Table 4 Correlating lithology deduced from geophysics with the drilling results (Okrah et al. 2012)

\begin{tabular}{|c|c|c|c|c|c|c|}
\hline \multicolumn{2}{|l|}{ Borehole site } & \multicolumn{2}{|l|}{ Drilling log } & \multicolumn{3}{|l|}{ Geophysics } \\
\hline Community & VES Point & Lithology & Thickness (m) & Resistivity ( $\Omega \mathrm{m})$ & Thickness & Layer \\
\hline \multirow[t]{3}{*}{ Community } & & Sandy-clay and gravel & $0-2$ & 147.7 & 2.7 & 1 \\
\hline & & Sandy-clay & $2-10$ & & & 2 \\
\hline & & Sandy-clay and gravel & $10-18$ & 286.8 & 15.9 & 3 \\
\hline \multirow[t]{3}{*}{ Buabinso } & B30 & Rusty weathered phyllite & $18-38$ & 57.7 & & \\
\hline & & Weathered granite & $27-33$ & - & - & - \\
\hline & & Fresh granite & $33-51$ & & & \\
\hline
\end{tabular}


Table 5 Longitudinal unit conductance, aquifer protective capacity and groundwater potential of the study area

\begin{tabular}{|c|c|c|c|c|c|c|c|c|}
\hline VES station ID & $\mathrm{N}$ & W & $\mathrm{S}(\Omega)$ & $\begin{array}{l}\text { Protective } \\
\text { capacity rating }\end{array}$ & $\begin{array}{l}\text { Overburden } \\
\text { thickness (m) }\end{array}$ & Reflection coefficient & $\begin{array}{l}\text { Groundwater } \\
\text { potential yield }\end{array}$ & $\begin{array}{l}\text { Numeri- } \\
\text { cal } \\
\text { weight }\end{array}$ \\
\hline A60 & 6.228567 & 2.035633 & 8.316607 & Very good & 84.2 & 0.957041 & Medium & 3 \\
\hline A140 & 6.227917 & 2.035967 & 8.960241 & Very good & 83 & 0.957041 & Medium & 3 \\
\hline B78 & 6.228833 & 2.035900 & 3.360822 & Good & 88.8 & 0.832258 & Medium & 3 \\
\hline A182 & 6.227583 & 2.036150 & 2.281077 & Good & 30.9 & 0.96357 & Medium & 3 \\
\hline D78 & 6.213717 & 2.044633 & 0.017146 & Poor & 16.2 & -0.72666 & High & 4 \\
\hline Existing $\mathrm{BH}$ & 6.211567 & 2.045283 & 0.292576 & Moderate & 52 & -0.94425 & High & 4 \\
\hline C52 & 6.209400 & 2.045933 & 0.105284 & Weak & 16.3 & 0.678815 & High & 4 \\
\hline C188 & 6.049683 & 1.958400 & 0.287409 & Moderate & 9.54 & 0.269841 & Very low & 1 \\
\hline $\mathrm{B} 50$ & 6.061333 & 1.941533 & 0.039564 & Poor & 7.52 & -0.62887 & Very low & 1 \\
\hline B76 & 6.058167 & 1.958450 & 0.948317 & Good & 40.3 & 0.974874 & Medium & 3 \\
\hline Existing $\mathrm{BH}$ & 6.047983 & 1.960600 & 0.337639 & Moderate & 6.92 & 0.777778 & Very low & 1 \\
\hline B145 & 6.054500 & 1.958883 & 1.241178 & Good & 6.52 & 0.945578 & Low & 2 \\
\hline $\mathrm{C} 150$ & 6.049283 & 1.958683 & 1.406601 & Good & 26.6 & 0.992806 & Medium & 3 \\
\hline A130 & 6.044233 & 1.964450 & 1.18848 & Good & 31.7 & 0.991682 & Medium & 3 \\
\hline A88 & 6.044617 & 1.964567 & 1.458603 & Good & 17.7 & 0.996226 & Medium & 3 \\
\hline $\mathrm{C} 80$ & 6.049283 & 1.959317 & 1.184153 & Good & 23.5 & 0.995072 & Medium & 3 \\
\hline A168 & 5.958567 & 1.822500 & 0.780406 & Moderate & 25.8 & -0.67619 & High & 4 \\
\hline A52 & 5.959483 & 1.831250 & 1.210402 & Good & 29.4 & 0.421053 & High & 4 \\
\hline C62 & 5.965733 & 1.827333 & 0.181562 & Weak & 18.1 & -0.88368 & High & 4 \\
\hline A142 & 5.958783 & 1.830900 & 0.286963 & Moderate & 10.7 & 0.423077 & Very low & 1 \\
\hline B75 & 5.958850 & 1.830783 & 0.47279 & Moderate & 12.2 & 0.529412 & Very low & 1 \\
\hline A100 & 5.959117 & 1.831050 & 2.255097 & Good & 83 & 0.333333 & High & 4 \\
\hline C115 & 5.965583 & 1.823667 & 0.515677 & Moderate & 32.8 & 0.970985 & Medium & 3 \\
\hline C65 & 5.925050 & 1.689483 & 0.094295 & Poor & 30.1 & 0.916548 & Medium & 3 \\
\hline D98 & 5.922617 & 1.691900 & 0.154343 & Weak & 43.6 & 0.944738 & Medium & 3 \\
\hline D42 & 5.923033 & 1.691767 & 0.140604 & Weak & 38.7 & 0.956122 & Medium & 3 \\
\hline $\mathrm{C} 115$ & 5.924200 & 1.714500 & 0.124983 & Weak & 25.2 & 0.992958 & Medium & 3 \\
\hline A172 & 5.927917 & 1.677333 & 0.136576 & Weak & 25.8 & 0.97822 & Medium & 3 \\
\hline B60 & 5.923617 & 1.698183 & 0.124339 & Weak & 21.6 & 0.991114 & Medium & 3 \\
\hline A95 & 5.927567 & 1.705167 & 0.038164 & Poor & 52.7 & 0.919204 & Medium & 3 \\
\hline A130 & 5.927833 & 1.707167 & 0.036606 & Poor & 23.5 & 0.994958 & Medium & 3 \\
\hline A42 & 5.880817 & 1.759150 & 0.158565 & Weak & 56.6 & 0.596971 & High & 4 \\
\hline B112 & 5.880117 & 1.758883 & 0.056081 & Poor & 27.8 & 0.96978 & Medium & 3 \\
\hline A240 & 5.879067 & 1.758900 & 0.064266 & Poor & 34.4 & 0.992106 & Medium & 3 \\
\hline A110 & 5.880150 & 1.759567 & 0.059716 & Poor & 33.3 & 0.990766 & Medium & 3 \\
\hline Existing $\mathrm{BH}$ & 5.879067 & 1.758233 & 0.076732 & Poor & 83 & 0.908341 & Medium & 3 \\
\hline B68 & 5.880050 & 1.759283 & 0.089349 & Poor & 77.7 & 0.977132 & Medium & 3 \\
\hline
\end{tabular}

intrusion. The assessment of the protective capacity of the aquifer showed very good $(5 \%)$, good $(27 \%)$, moderate $(19 \%)$, and weak $(22 \%)$ and poor $(27 \%)$. The study area is overlain mostly by materials of different protective capacities. The study shows that the Tarkwaian formation has poorer aquifer protective capacity as compare to the Birimian formation. It is, therefore, important for the groundwater resources to be protected from surface contaminates in the study area, especially in the Tarkwaian formation. This is because the groundwater in the formation is vulnerable to surface contaminants such as mining waste, sewage, effluent and indiscriminate waste disposal in the study area. The study has confirmed that geophysical techniques are an effective scientific tool in groundwater exploration.

Acknowledgements The author is grateful to the Management of the Community Water and Sanitation Agency, Cape Coast for making the data available for this study. 
Funding No funding was received by the author.

\section{Declaration}

Conflict of interest The author declares that he has no conflict of interest.

Open Access This article is licensed under a Creative Commons Attribution 4.0 International License, which permits use, sharing, adaptation, distribution and reproduction in any medium or format, as long as you give appropriate credit to the original author(s) and the source, provide a link to the Creative Commons licence, and indicate if changes were made. The images or other third party material in this article are included in the article's Creative Commons licence, unless indicated otherwise in a credit line to the material. If material is not included in the article's Creative Commons licence and your intended use is not permitted by statutory regulation or exceeds the permitted use, you will need to obtain permission directly from the copyright holder. To view a copy of this licence, visit http://creativecommons.org/licenses/by/4.0/.

\section{References}

Abbas AM, Atya MA, Al-Sayed EA, Kamei H (2004) Assessment of groundwater resources of the Nuweiba area at Sinai Peninsula, Egypt by using geoelectric data corrected for the influence of near surface inhomogeneities. J Appl Geophys 56:107-122

Abouchami W, Boher M, Michard A, Albarede F (1990) A major $2.1 \mathrm{Ga}$ events of magmatism in West Africa: an early stage of crustal accretion. J Geophys Res 95:17605-17629

Anornu GK, Kortatsi BK, Saeed ZM (2009a) Evaluation of groundwater resources potential in the Ejisu-Juaben District of Ghana. Afr J Environ Sci Technol 3(10):332-340

Anornu Gk, Kortatsi BK, Saeed ZM (2009b) Evaluation of groundwater resources potential in the Ejisu-Juaben district of Ghana. Afr J Environ Sci Technol. https://doi.org/10.4314/ajest.v3i10.56261

Bayewu OO, Oloruntola MO, Mosuro GO, Laniyan TA, Ariyo SO, Fatoba JO (2018) Assessment of groundwater prospect and aquifer protective capacity using resistivity method in Olabisi Onabanjo University campus, Ago-Iwoye, Southwestern Nigeria. NRIAG J Astron Geophys 7(2018):347-360

Bhattacharya PK, Patra HP (1968) Direct current geoelectric sounding methods in geochemistry and geophysics. Elsevier, Amsterdam, p $135 \mathrm{p}$

Carrier MA, Lefebre R, Racicot J, Asare EB (2008a) Groundwater recharge assessment in northern Ghana using soil moisture balance and chloride mass balance. GeoEdmonton 8:1437-1444

Carrier MA, Lefebvre R, Racicot J, Asare EB (2008) Northern Ghana hydrogeological assessment project. In: 33rd WEDC international conference, Accra, Ghana.

Central Ashanti Gold Limited (2010) Environmental impact statement central Ashanti Gold Project. Volume 1 Final. March 2010.

Clark L (1985) Groundwater abstraction from Basement Complex areas of Africa. Q J Eng Geol 18:25-32

Coffey Mining Pty Ltd (2007) Ayanfuri tailings water balance (unpublished spreadsheet)

CSIR-WRI Database (1996) Existing boreholes in upper Denkyira District

CSIR-WRI Database (2007) Existing boreholes in upper Denkyira District

Dapaah-Siakwan S, Gyau-Boakye P (2000) Hydrogeologic framework and borehole yields in Ghana. Hydrogeol $\mathbf{J}$ (springerVerlag) 8:405-416
Dickson KB, Benneh G (1980) A new geography of Ghana. Longman, London

European Environment Agency (1999) Groundwater quality and quantity in Europe: data and basic information. Technical report, Copenhagen

Geological Survey Department, G. (2009). Geological map of Ghana 1: 000 000. Geological Map of Ghana. Geological Survey Department, GSD

Golam SS, Keramat M, Shalid M (2014) Deciphering transmissivity and hydraulic conductivity of the aquifer by vertical electrical sounding (VES) experiments in Northwest Bangladesh. Appl Water Sci 6:35-45

Griffis RJ, Barning K, Agezo FL, Akosah FK (2002) Gold deposits of Ghana. Minerals Commission Report

Henriet JP (1976) Direct application of Dar-Zarrouk parameters in ground water surveys. Geophys Prospect 24:344-353

Jones MJ (1985) The weathered zone aquifers of the basement complex areas of Africa. Q J Eng Geol 18:35-46

Junner NR (1935) Gold in the gold coast, gold coast geological survey memorandum no. 4, Accra, $67 \mathrm{pp}$

Keller GV (1967) Application of resistivity methods in mineral and groundwater exploration program. In: Mining and groundwater geophysics, geological survey of Canada, no. 26, pp. 51-66

Keller GV, Frischknecht FC (1966) Electrical methods in geophysical prospecting. Pergamon Press, Oxford

Kesse GO (1985) The mineral and rock resources of Ghana. Ballkema Publishers, Rotterdam, p 610

Koefoed O (1979) Geosounding principles 1. Resistivity sounding measurements. Elsevier, Amsterdam, p 275

Kortatsi BK (1994) Groundwater utilization in Ghana. In: Proceedings of the Helsinki conference. IAHS Publ. No. 222

Kosinski WK, Kelly WE (1981) Geoelectric soundings for predicting Aquifer properties. Groundwater 19:163-171

Leube A, Hirdes W, Mauer R, Kesse GO (1990) The early Proterozoic Birimian Supergroup of Ghana and some aspects of its associated gold mineralization. Precambrian Res 46:139-165

Loke MH (1999)Time-lapse resistivity imaging inversion. In: Proceedings of the 5th meeting of the environmental and engineering geophysical society European Section, Em1. 90pp

Margat J, van-der Gun J (2013) Groundwater around the World. CRC Press/Balkema, Boca Raton

Ogunrayi AO, Akinseye FM, Goldberg V, Bernhofer C (2016) Descriptive analysis of rainfall and temperature trends over Akure, Nigeria. J Geogr Reg Plan 9(11):195-202

Okrah C, Danuor SK, Dapaah-Siakwan S (2012) Geophysical investigations for groundwater in the middle Precambrian province of Upper Denkyira District using electromagnectic and electrical resistivity methods. J Ghana Sci Assoc 14(1):103

Oladapo MI, Akintorinwa OJ (2007) Hydrogeophysical study of Ogbese Southwestern, Nigeria. Glob J Pure Appl Sci 13(1):55-61

Olayinka AI (1996) Non uniqueness in the interpretation of bedrock resistivity from sounding curves and its hydrological implications. Water Resour NAH 7(1 \& 2):55-60

Olorunfemi MO, Ojo JS, Oladapo MI (1998) Geological hydrogeological and geophysical investigations of exposed 20" Escravos Lagos Pipeline. Technical Report

Pous J, Queralt P, Chavez R (1996) Lateral and topographic effects in geoelectric soundings. J Appl Geophys 35:237-248

United Nations Economic Commission for Europe (1999) Inventory of transboundary groundwaters

Wyllie MRJ (1963) The fundamentals of well log interpretation. Academic Press, New York

Publisher's Note Springer Nature remains neutral with regard to jurisdictional claims in published maps and institutional affiliations. 